\title{
Meningkatkan Prestasi Belajar IPA Siswa Menggunakan Multimedia Pembelajaran Sistem Tata Surya pada Siswa Kelas IX SMP Negeri 1 Selesai Tahun Ajaran 2016/2017
}

\author{
Lambue Ritonga \\ SMP Negeri 1 Selesai, Langkat, Sumatera Utara, Indonesia \\ E-mail: lambueritonga@gmail.com
}

\begin{abstract}
Abstrak
Tujuan penelitian tindakan kelas ini adalah untuk meningkatkan prestasi belajar IPA melalui penggunaan multimedia. Penelitian ini terdiri dari 2 Siklus, masing-masing 2 pertemuan. Pada observasi awal diketahui bahwa nilai rata-rata hasil belajar yang diperoleh 64,7 dengan ketuntasan 41,2\%. Pada Siklus I nilai rata-rata mencapai 75,6 dengan ketuntasan $70,6 \%$. Dan pada siklus II nilai rata-rata yang mencapai 82,6 dengan ketuntasan 85,3\%. Aktivitas belajar siswa selama proses belajar-mengajar juga terjadi peningkatan. Pada Siklus I pertemuan 1 keaktifan belajar siswa pada kategori kurang (37,5\%), dan pada pertemuan 2 masih kategori kurang (50\%). Pada Siklus II pertemuan 1 keaktifan belajar siswa pada kategori cukup $(68,75 \%)$, dan pada pertemuan 2 kategori baik sekali $(93,75 \%)$. Hal ini menunjukkan bahwa penggunaan Multimedia di kelas IX-4 SMP Negeri 1 Selesai Tahun Pelajaran 2016/2017 dapat meningkatkan baik hasil belajar IPA maupun aktivitas belajar siswa.
\end{abstract}

Kata Kunci: hasil belajar, aktivitas belajar, multimedia

\begin{abstract}
The purpose of this Classroom Action Research is to improve the student's natural science through multimedia. It is carried out in 2 Cycles, each of which is 2 meetings. The students' average achievement baseline is 64.7 at $41.2 \%$ mastery learning. In Cycle I the achievement is 75.6 at $70.6 \%$ mastery learning. In Cycle II the achievement is 82.6 at $85.3 \%$ mastery learning. Students' activities also increase. In Cycle I meeting 1 is categorized bad and in meeting 2 is still categorized bad. In Cycle 2 meeting 1 is categorized fair, and in meeting 2 increases to very good. It shows that the application of multimedia to the 2015/2016 Grade IX-3 students of Public JHS 1
\end{abstract}

Meningkatkan Prestasi Belajar ... (Ritonga, L.,68-82) 68 
Selesai improves both their natural science achievement and learning activities.

Keywords: learning achievement, learning activity, multimedia

\section{A. PENDAhULUAN}

Permasalahan mutu pembelajaran seringkali dikaitkan dengan merosotnya prestasi atau hasil belajar yang dicapai peserta didik. Sehubungan dengan hal tersebut di atas, maka hal semacam itu harus dikaji secara cermat melalui komponen-komponen penting dalam sistem pendidikan yang berkaitan agar dapat dilakukan upaya penanggulangannya.

Untuk itu terwujudnya kondisi pembelajaran siswa aktif merupakan harapan dari semua komponen pendidikan termasuk masyarakat dan praktisi pendidikan. Oleh karena itu dalam kegiatan pembelajaran dituntut suatu strategi pembelajaran yang direncanakan oleh guru dengan mengedepankan keaktifan siswa dalam kegiatan belajar mengajar. Melalui kegiatan belajar yang menekan pada aktivitas siswa diharapkan mampu meningkatkan motivasi dan hasil belajar yang sesuai dengan tujuan pendidikan di sekolah.

Siswa yang aktif dalam proses pembelajaran dicirikan oleh dua aktivitas, yaitu aktivitas dalam berpikir (minds-on), dan aktivitas dalam berbuat (hands-on). Perbuatan nyata siswa dalam pembelajaran merupakan hasil keterelibatan berpikir siswa terhadap kegiatan belajarnya. Denga demikian proses siswa aktif dalam kegiatan belajar mengajar merupakan suatu kegiatan pembelajaran yang harus dilaksanakan secara terus menerus dan tidak berhenti. Hal ini dilakukan apabila interaksi antara guru dan siswa terjalin dengan baik.

Seiring dengan perkembangan jaman, setiap bangsa dituntut untuk menjadi bangsa yang berkualitas. Sumber daya manusia yang berkualitas sangat diperlukan untuk dapat bersaing dengan bangsabangsa lain. Salah satu upaya untuk meningkatkan kualitas sumber daya manusia adalah dengan cara memperbaiki mutu pendidikan. Pendidikan merupakan suatu dasar pembangunan watak, mental dan spiritual manusia, sehingga pendidikan suatu bangsa dapat merupakan tolak ukur kualitas bangsa.

Perbaikan mutu pendidikan di Indonesia selalu dilaksanakan dengan berbagai cara. Salah satu upaya yang ditempuh untuk 
meningkatkan mutu pendidikan adalah melalui peningkatan mutu proses pembelajaran yang pada akhirnya akan meningkatkan mutu pendidikan di sekolah. Sekolah adalah bagian dari masyarakat yang merupakan tempat bagi pembinaan sumber daya manusia yang sesuai dengan perkembangan jaman.

Pendidikan di sekolah tak bisa lepas dari proses kegiatan belajar mengajar yang meliputi seluruh aktivitas yang menyangkut pelaksanaan kegiatan belajar mengajar dan pemberian materi pelajaran agar siswa memperoleh kecakapan pengetahuan yang bermanfaat bagi kehidupan. Proses pelaksanaan pemberian materi yang baik akan memudahkan siswa untuk Mendeskripsikan materi yang sedang diajarkan, sehingga tujuan pembelajaran akan mudah dicapai.

Salah satu materi pelajaran yang ada di sekolah adalah Ilmu Pengetahuan Alam (IPA). IPA adalah ilmu pengetahuan yang merupakan gejala alam, baik yang menyangkut makhluk hidup maupun benda mati. Pada prinsipnya, IPA diajarkan untuk membekali siswa agar mempunyai pengetahuan (mengetahui berbagai cara) dan ketrampilan (cara mengerjakan) yang dapat membantu siswa untuk memahami gejala alam secara mendalam.

Selain itu, juga untuk menyadari akan kebesaran Tuhan Yang Maha Kuasa, pelaksanaan pembelajaran IPA tidak selamanya selalu berjalan lancar. Mata pelajaran IPA membutuhkan suatu percobaan. Sesuai dengan daya pikir anak sekolah dasar yang masih digunakan dalam pola pikir yang kongrit, maka dalam proses pembelajaran yang abstrak harus dibantu agar pembelajaran menjadi kongrit. Sesuai dengan keadaan yang diamati, siswa sulit memahami konsep system tata surya dikarenakan kurang motivasi belajar siswa.

Dari hasil observasi awal terlihat dari sekitar $40 \%$ dari 34 siswa tidak bisa menjawab ketika guru bertanya. Dan dalam proses kegiatan belajar siswa banyak yang ramai. Tidak memperhatikan penjelasan guru, kegiatan belajar mengajar guru mengajarkan dengan ceramah dan tanpa alat peraga, sehingga siswa tidak tertarik mengikuti kegiatan belajar mengajar, siswa hanya mendengarkan ceramah guru tanpa melakukan kegiatan pengamatan, pengukuran, pengurai perbedaan, percobaan, dan sebagainya. Siswa juga tidak berinteraksi langsung terhadap obyek yang dipelajari dengan melibatkan semua alat inderanya. Hal tersebut menyebabkan siswa kurang memahami 
konsep system tata surya. Oleh karena itu, artikel ini memaparkan penggunaan multimedia topik sistem tata surya pada siswa kelas IX-4 SMP Negeri 1 Selesai.

\section{B. TINJAUAN PUSTAKA \\ 1. Pengertian Prestasi Belajar}

Istilah prestasi belajar dalam dunia pendidikan menjadi sesuatu hal yang menarik untuk dibahas, karena keberadaannya sangat bermnfaat bagi pendidik, siswa, maupun orang tua. Prestasi belajar bagi pendidik dapat dijadikan tolok ukur tentang sejauh mana keberhasilan kegiatan pembelajaran yang sudah dilakukan terhadap siswanya. Bagi siswa pencapaian prestasi belajar dapat memberi gambaran tentang hasil dari usaha yang telah dilaksanakannya, sedagkan bagi orang tua dengan mengetahui prestasi belajar siswa, maka akan dapat mengetahui tingkat keberhasilan putra-putrinya di sekolah, selanjutnya dijadikan bahan pertimbangan untuk memberikan dorongan dan pengawasan di rumah.

Menurut Arifin (2009: 12) prestasi belajar merupakan suatu masalah yang bersifat perenial dalam sejarah kehidupan manusia, karena sepanjang rentang kehidupannya manusia selalu mengejar prestasi menurut bidang dan kemampuan masing-masing. Menurut Syah (2004: 216) prestasi belajar adalah hasil usaha bekerja atau belajar yang menunjukan ukuran kecakapan yang dicapai dalam bentuk nilai, yang telah dicapai oleh seseorang dan ditunjukkan dalam jumlah nilai raport atau tes sumatif.

Berdasarkan pendapat para ahli di atas dapat disimpulkan bahwa prestasi belajar adalah hasil dari suatu usaha yang diperoleh melalui keuletan kerja yang dicapai dalam bentuk nilai yang telah diperoleh seseorang. Pada penelitian ini prestasi belajar yang dimaksudkan adalah nilai akhir siswa setelah menggunakan multimedia Sistem Tata Surya pada mata pelajaran IPA.

\section{Cara Mengukur Prestasi Belajar}

Dalam proses belajar mengajar, khususnya untuk mengevaluasi hasil belajar siswa pada umumnya digunakan tes hasil belajar atau tes prestasi belajar. Istilah tes merupakan alat atau prosedur yang digunakan untuk mengetahui, atau mengukur sesuatu dalam suasana, dengan cara dan aturanaturan yang sudah ditentukan 
(Arikunto, 1999: 53). Ada beberapa pendapat dari beberapa ahli tentang pengertian, tes adalah salah satu tes statistik yang dipergunakan untuk menguji kebenaran/ kepalsuan hipotesa nihil yang mengatakan bahwa dianatara dua buah mean sampel yang diambil secara random dari populasi yang sama, tidak tedapat perbedaan yang signifikan (Sudijono, 1996: 264).

Dari pengertian para ahli tersebut dalam dunia pendidikan dapat disimpulkan bahwa pengertian tes adalah cara yang digunakan atau proseduryang ditempuh dalam rangka pengukuran dan penilaian di bidang pendidikan, yang memberikan tugas dan serangkaian tugas yang diberikan oleh guru sehingga dapat dihasilkan nilai yang melambangkan tingkat atau prestasi belajar siswa.

\section{Pembelajaran IPA di SMP}

\section{1 Pengertian Pembelajaran}

Pembelajaran merupakan bantuan yang diberikan pendidik agar dapat terjadi proses pemerolehan ilmu dan pengetahuan, penguasaan kemahiran dan tabiat, serta pembentukan sikap dan kepercayaan pada siswa. Dengan kata lain, pembelajaran adalah proses untuk membantu siswa agar dapat belajar dengan baik.

Menurut Sagala (2010: 61), pembelajaran ialah membelajarkan siswa menggunakan asas pendidikan maupun teori belajar, merupakan penentu utama keberhasilan pendidikan. Pembelajaran merupakan komunikasi dua arah. Mengajar dilakukan oleh pihak guru sebagai pendidik, sedangkan belajar dilakukan oleh siswa atau murid.

Berdasarkan pendapat di atas dapat dijelaskan bahwa pembelajaran adalah usaha sadar dari guru untuk membuat siswa belajar, yaitu terjadinya perubahan tingkah laku pada diri siswa yang belajar, dimana perubahan itu dengan didapatkannya kemampuan baru yang berlaku dalam waktu yang relatif lama dan karena adanya usaha.

\subsection{Hakikat Pembelajaran IPA di SMP}

Darmodjo dan Kaligis (1993: 12) menyatakan bahwa mengajar dan belajar merupakan suatu proses yang tidak dapat dipisahkan dalam pembelajaran. Pembelajaran akan berhasil apabila terjadi proses mengajar dan proses belajar yang harmoni. Proses belajar mengajar tidak dapat berlangsung hanya dalam satu arah, melainkan dari 
berbagai arah (multiarah) sehingga memungkinkan siswa untuk belajar dari berbagai sumber belajar yang ada.

Ilmu Pengetahuan Alam sebagai disiplin ilmu dan penerapannya dalam masyarakat membuat pendidikan IPA menjadi penting, karena struktur kognitif anak tidak dapat dibandingkan dengan struktur kognitif ilmuwan. Anak perlu dilatih dan diberi kesempatan untuk mendapatkan keterampilan-keterampilan dan dapat berpikir serta bertindak secara ilmiah.

Menurut Sulistyorini (2007: 8), pembelajaran IPA harus melibatkan keaktifan anak secara penuh (active learning) dengan cara guru dapat merealisasikan pembelajaran yang mampu memberi kesempatan pada anak didik untuk melakukan keterampilan proses meliputi: mencari, menemukan, menyimpulkan, mengkomunikasikan sendiri berbagai pengetahuan, nilai-nilai, dan pengalaman yang dibutuhkan.

Dalam hal ini juga digunakan sikap tertentu, misalnya berusaha berlaku seobjektif mungkin dan jujur dalam mengumpulkan dan mengevaluasi data. Proses dan sikap ilmiah ini akan melahirkan penemuan-penemuan baru yang menjadi produk IPA. Jadi dalam pembelajaran IPA siswa tidak hanya diberi pengetahuan saja atau berbagai fakta yang dihafal, tetapi siswa dituntut untuk aktif menggunakan pikiran dalam mempelajari gejala-gejala alam.

Dengan demikian pembelajaran IPA di SMP dapat memberikan kesempatan kepada siswa untuk mengembangkan keterampilan keterampilannya dan dapat melatih siswa untuk dapat berpikir serta bertindak secara rasional dan kritis terhadap persoalan yang bersifat ilmiah yang ada di lingkungannya. Keterampilan-keterampilan yang diberikan kepada siswa sebisa mungkin disesuaikan dengan tingkat perkembangan usia dan karakteristik siswa Sekolah Dasar, sehingga siswa dapat menerapkannya dalamkehidupannya sehari-hari.

\subsection{Prinsip-Prinsip Pembelajaran IPA}

Pembelajaran di sekolah dasar akan efektif bila siswa aktif berpartisipasi dalam proses pembelajaran. Oleh sebab itu guru sekolah dasar perlu menerapkan prinsip-prinsip pembelajaran di sekolah dasar. Menurut Sulistyorini (2007: 43) untuk mengajarkan IPA dikenal beberapa pendekatan, yakni (1) pendekatan kepada fakta-fakta, (2) pendekatan konsep, dan (3) pendekatan proses. Pendekatan yang 
menggunakan pendekatan faktual terutama bermaksud menyodorkan penemuan-penemuan IPA. Pendekatan ini tidak mencerminkan gambaran yang sebenarnya tentang sifat IPA. Selanjutnya pendekatan konsep adalah suatu ide yang mengikat banyak fakta menjadi satu.

Untuk memahami suatu konsep, anak perlu bekerja dengan objek-objek kongkret, memperoleh fakta-fakta, melakukan eksplorasi dan manipulasi ide secara mental, tidak sekedar menghafal. Oleh karena itu, pendekatan konsep memberikan gambaran lebih jelas tentang IPA dibandingkan dengan pendekatan faktual. Kemudian suatu pendekatan proses dalam pembelajaran IPA didasarkan atas pengamatan yang disebut sebagai keterampilan proses dalam IPA.

Berdasarkan definisi-definisi di atas, dapat disimpulkan bahwa pendekatan keterampilan proses merupakan pendekatan yang sesuai. Karena dalam pembelajaran IPA siswa memperoleh dan menemukan kosep melalui pengalaman sendiri, sekaligus belajar proses dan produk. Jadi di dalam pembelajaran yang menggunakan keterampilan proses terkandung dimensi proses, produk dan pengembangan sikap. Pembelajaran di SMP akan efektif bila siswa aktif berpartisipasi dalam proses pembelajaran. Oleh sebab itu guru SMP perlu menerapkan prinsip-prinsip pembelajaran IPA di SMP.

\subsection{Sistem Tata Surya}

Tata surya merupakan sebuah sistem yang terdiri dari Matahari, delapan planet, planet-kerdil, komet, asteroid dan bendabenda angkasa kecil lain. Matahari merupakan pusat dari Tata Surya di mana anggota Tata Surya yang lain beredar mengelilingi Matahari.

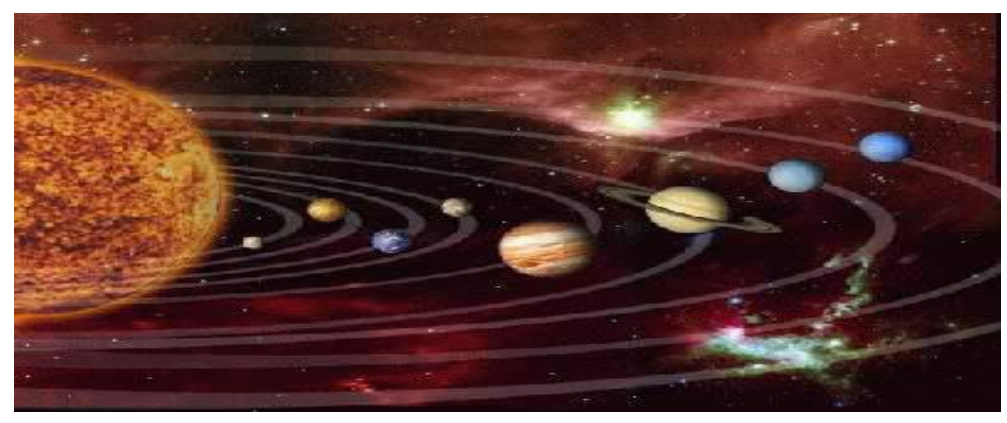

Gambar 1. Tata Surya 
Adapun uraian materi pembelajaran Sistem Tata Surya pada pembelajaran IPA menurut Maulana dan Ono (2008: 4) yakni: 1) Matahari, 2) Planet, 3) Planet-Kerdil, 4) Satelit, 5) Asteroid, dan 6) Komet.

\section{Media Pembelajaran}

Media pembelajaran merupakan alat bantu proses belajar mengajar, yang dipergunakan untuk merangsang pikiran, perasaan, perhatian dan kemampuan atau keterampilan siswa sehingga dapat mendorong terjadinya proses belajar. Pentingnya media pembelajaran karena penggunaan media tersebut dalam kegiatan belajar mengajar mampu mengatasi kerumitan bahan atau materi ajar yang akan disampaikan kepada siswa.

\section{Multimedia Pembelajaran}

\subsection{Pengertian Multimedia Pembelajaran}

Multimedia adalah gabungan dari teks, gambar, suara, animasi dan video, beberapa komponen tersebut atau seluruh komponen tersebut dimasukan ke dalam program yang koheren (Phillips, 1997: 8). Multimedia adalah penggunaan komputer untuk menyajikan dan menggabungkan teks, suara, gambar, animasi dan video dengan alat bantu (tool) dan koneksi (link) sehingga pengguna dapat bernavigasi, berinteraksi, berkarya dan berkomunikasi (Hofstetter, 2001: 44). Multimedia didefinisikan sebagai beberapa unsur yang terintegrasi kedalam media (audio, video, grafik, teks, animasi, dan lain-lain) menjadi satu kesatuan yang sinergis dan simbiosis yang memberikan keuntungan bagi pengguna maupun individu (Hadi, 2003: 3).

Dari beberapa pengertian multimedia yang dikemukakan oleh para ahli tersebut dapat ditarik kesimpulan bahwa multimedia merupakan suatu gabungan antara teks, gambar, grafis, animasi, audio dan video, serta cara penyampaian interaktif sehingga dapat membuat suatu pengalaman belajar bagi siswa seperti dalam kehidupan nyata disekitarnya. Multimedia dapat berfungsi menjadi sebuah sistem karena merupakan sekumpulan objek yang berhubungan dan bekerjasama untuk menghasilkan suatu hasil yang diinginkan.

Sedangkan pembelajaran dapat diartikan sebagai proses penciptaan lingkungan yang memungkinkan terjadinya proses belajar. Dengan demikian multimedia pembelajaran merupakan aplikasi 
multimedia yang digunakan dalam proses pembelajaran dalam menyalurkan pesan (pengetahuan, keterampilan dan sikap) serta dapat merangsang pikiran, perasaan, perhatian dan kemauan belajar sehingga proses belajar terjadi, bertujuan dan terkendali.

\subsection{Komponen Multimedia}

Menurut Hadi (2003: 8) beberapa unsur untuk mengembangkan sebuah program multimedia adalah sebagai berikut.

\section{a. Teks}

Tampilan dalam bentuk teks atau yang lebih dikenal dengan istilah tipografi merupakan elemen yang cukup penting dalam pembuatan multimedia. Sebagian besar multimedia menggunakan teks karena sangat efektif untuk menyampaikan ide dan panduan kepada pengguna.

\section{b. Grafik (Gambar)}

Grafik atau gambar merupakan sarana pembentukan informasi yang lebih mudah untuk dipahami. Gambar juga merupakan salah satu komponen penting dalam multimedia karena dapat meringkas dan menyajikan data kompleks serta mampu menyampaikan banyak kata.

\section{c. Audio}

Teknologi audio juga berperan penting dalam melengkapi penyampaian informasi. Suara atau audio di dalam multimedia biasanya berupa suara musik, suara dari voice record dan efek-efek suara lain.

\section{d. Video}

Video adalah gambar-gambar yang berurutan sehingga menimbulkan efek gerak. Video dalam tampilan multimedia bertujuan untuk membuat tampilan yang dihasilkan lebih menarik.

\section{e. Animasi}

Animasi merupakan kumpulan gambar yang ditampilkan secara bergantian dan berurutan sehingga terlihat bergerak dan hidup. Pergerakan animasi mempermudah pemahaman terhadap informasi yang disampaikan.

\subsection{Manfaat Multimedia dalam Pembelajaran}

Multimedia pembelajaran memberikan manfaat dalam beberapa situasi dalam belajar mengajar. Philips (1997: 12) menyatakan bahwa "IMM has the potential to accommodate people 
with different learning style". Multimedia interktif memiliki potensi untuk menciptakan suatu lingkungan multisensor yang mendukung cara belajar tertentu. Multimedia dalam proses belajar mengajar dapat digunakan dalam tiga fungsi: 1) multimedia dapat berfungsi sebagai alat bantu instruksional, 2) multimedia dapat berfungsi sebagai tutorial interaktif, misalnya dalam simulasi, dan 3) multimedia dapat berfungsi sebagai sumber petunjuk belajar, misalnya, multimedia digunakan untuk menyimpan serangkaian slide mikroskop atau radiograf.

\subsection{Multimedia Pembelajaran Sistem Tata Surya}

Multimedia pembelajaran Sistem Tata Surya adalah sumber belajar yang melibatkan siswa secara auditif, visual dan kinetik dalam pembelajaran mandiri yang memiliki kontrol pemanfaatan penuh oleh pengguna dan di dalamnya menyediakan umpan balik secara segera dengan tujuan memudahkan terjadinya proses belajar baik individu atau kelompok

Arsyad (2011: 171) menyebutkan bahwa multimedia Sistem Tata Surya adalah berbagai macam kombinasi gabungan antara grafik, teks, suara, video, dan animasi. Penggabungan ini merupakan satu kesatuan yang secara bersama-sama menampilkan informasi, pesan atau isi pelajaran. Multimedia Sistem Tata Surya adalah suatu multimedia yang dilengkapi dengan alat pengontrol yang dapat dioperasikan oleh pengguna sehingga pengguna dapat memilih apa yang dikehendaki untuk proses selanjutnya.

\section{METODE}

Penelitian ini dilakukan pada siswa kelas IX-4 di SMP Negeri 1 Selesai, Langkat. Waktu penelitian dilakukan pada bulan Pebruari sampai dengan bulan Maret Tahun Pelajaran 2016/2017. Metode penelitian yang digunakan adalah Penelitian Tindakan Kelas (action research) yang terdiri atas dua siklus. Dimana setiap siklus terdiri atas perencanaan (planning), pelaksanaan (action), pengamatan (observation) dan refleksi (reflection). Data hasil belajar diambil dengan memberikan tes kepada siswa setelah proses pembelajaran berlangsung. Data aktivitas siswa diperoleh melalui pengamatan dengan menggunakan lembar pengamatan. Indikator keberhasilan hasil belajar minimal 80\% dari siswa mencapai KKM 75 . 


\section{HASIL DAN PEMBAHASAN}

1. Hasil

Penelitian ini dilaksanakan selama 2 Siklus, masing-masing 2 kali pertemuan. Pada tahap awal rata-rata hasil belajar siswa adalah 64,7 dengan persentase ketuntasan belajar sebesar 41,2\%. Pada Siklus 1 rata-rata hasil belajar 75,6 atau tuntas 70,6\%. Pada Siklus 2 rata-rata hasil belajar menjadi 82,6 dengan ketuntasan $85,3 \%$. Sementara, pada Siklus I pertemuan 1 keaktifan belajar siswa pada kategori kurang (37,5\%), dan pada pertemuan 2 masih kategori kurang (50\%). Pada Siklus II pertemuan 1 keaktifan belajar siswa pada kategori cukup $(68,75 \%)$, dan pada pertemuan 2 kategori baik sekali $(93,75 \%)$.

\section{Pembahasan}

\section{a. Deskripsi Awal Hasil Belajar dan Keaktifan Belajar}

Pada tahap awal, rata-rata perolehan prestasi belajar pada tahap awal hanya sebesar 64,7 dengan persentase ketuntasan sebesar $41,2 \%$. Kemudian pada siklus I, setelah menggunakan multimedia pembelajaran di kelas untuk mengajarkan materi IPA Sistem Tata Surya, terjadi peningkatan prestasi belajar siswa menjadi 75,6 dengan persentase ketuntasan sebesar 70,6\% dan pada siklus II meningkat lagi menjadi 82,6 dengan persentase ketuntasan sebesar 85,3\%. Hal ini menunjukkan bahwa dengan menggunakan multimedia pembelajaran di kelas IX-4 SMP Negeri 1 Selesai Tahun Pelajaran 2016/2017 prestasi belajar siswa meningkat.

\section{Tabel 1 Prestasi Belajar Siswa Pra-Siklus, Siklus I dan Siklus II}

\begin{tabular}{|c|c|c|c|}
\hline Instrumen & Nilai awal & Siklus I & Siklus II \\
\hline KKM & 75 & 75 & 75 \\
\hline Rata-rata & 64,7 & 75,6 & 82,6 \\
\hline Persentase Ketuntasan & $41,2 \%$ & $70,6 \%$ & $85,3 \%$ \\
\hline Jumlah Tuntas & 14 & 24 & 29 \\
\hline
\end{tabular}

Grafik perbandingan nilai prestasi belajar siswa pra-Siklus, Siklus I dan Siklus II dapat dilihat pada Grafik 1 di bawah ini. 


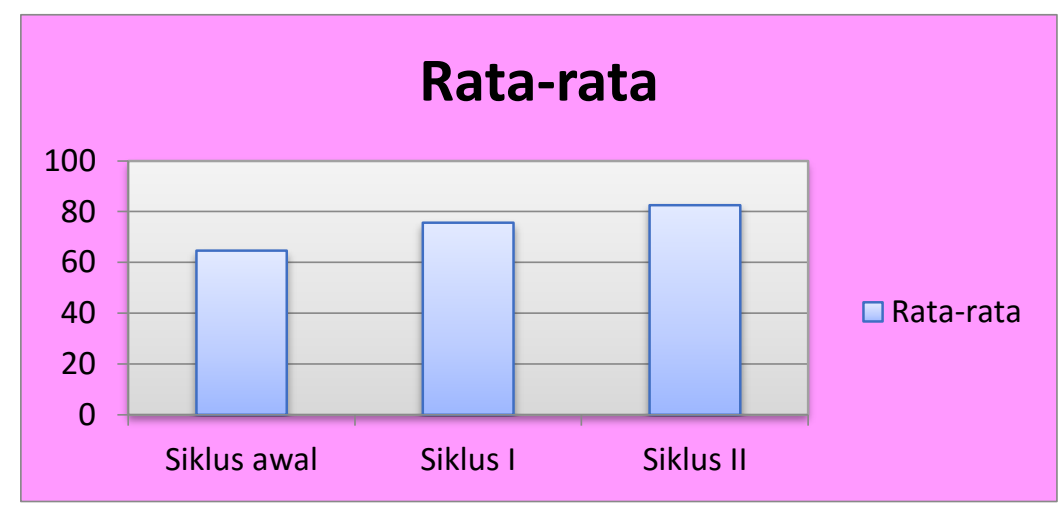

Grafik 1 Prestasi belajar siswa pra-Siklus, Siklus I dan Siklus II

Grafik perbandingan ketuntasan belajar siswa pra-Siklus, Siklus I dan Siklus II dapat dilihat pada Grafik 2 di bawah ini.

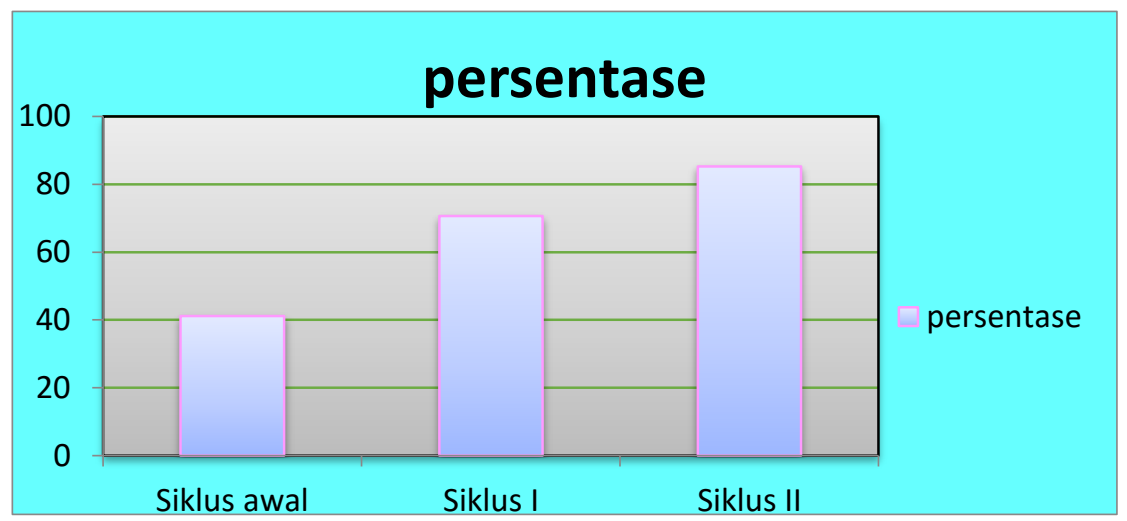

Grafik 2 Ketuntasan Belajar Siswa Pra-Siklus, Siklus I dan Siklus II

Selain prestasi belajar, aktivitas belajar siswa selama proses belajar-mengajar juga terjadi. Dimana pada siklus I pertemuan 1 kategori aktivitas belajar siswa yaitu kategori kurang dan pertemuan 2 adalah kategori cukup. Kemudian pada siklus II, aktivitas belajar siswa pertemuan 1 adalah kategori Baik dan pada pertemuan II adalah kategori Sangat baik.

\section{b. Deskripsi Hasil Belajar dan Keaktifan Belajar Siswa Siklus I}


Hasil belajar siswa menunjukkan peningkatan menjadi 75,45 dengan persentase ketuntasan sebesar 72,7\%. Namun demikian, hasil ini masih di bawah indikator keberhasilan.

Keaktifan belajar siswa pada pertemuan I masih sangat rendah yakni sebesar 34,6\%. Data menunjukkan bahwa belum sepenuhnya bahkan kurang dari setengah jumlah siswa yang aktif atau turut dalam pembelajaran yang sedang berlangsung di kelas. Pada pertemuan kedua keaktifan siswa menunjukkan perubahan menjadi 60,6\%. Data ini masih jauh berada di bawah indikator keberhasilan.

\section{c. Deskripsi Hasil Belajar dan Keaktifan Belajar Siswa Siklus II}

Pada Siklus II rata-rata hasil belajar siswa meningkat lagi menjadi 84,5 dengan persentase sebesar $87,8 \%$. Data ini menunjukkan bahwa hasil belajar siswa sudah melampaui indikator keberhasilan. Demikian juga dengan keaktifan belajar siswa, pada pertemuan I hasil keaktifan belajar siswa $84,8 \%$. Pada pertemuan kedua keaktifan siswa menunjukkan peningkatan menjadi $87,8 \%$ Data ini menunjukkan sudah berada di atas indikator keberhasilan.

\section{E. SIMPULAN}

\section{Kesimpulan}

Berdasarkan hasil penelitian tindakan kelas dalam proses perbaikan pembelajaran IPA materi sistem tata surya pada siswa kelas IX-4 SMP Negeri 1 Selesai Tahun Pelajaran 2016/2017 dengan menggunakan multimedia sistem pembelajaran untuk meningkatkan prestasi belajar dapat dibuat kesimpulan sebagai berikut. Pertama, prestasi belajar siswa pada kegiatan belajar mengajar meningkat pada setiap siklusnya. Hal ini terlihat dari prestasi belajar pada tahap awal hanya sebesar 64,7 dengan persentase ketuntasan sebesar 41,2\%. Kemudian pada siklus I, setelah peneliti melakukan multimedia pembelajaran di kelas untuk mengajarkan materi IPA Sistem Tata Surya, terjadi peningkatan prestasi belajar siswa menjadi 75,6 dengan persentase ketuntasan sebesar 70,6\% dan pada siklus II meningkat lagi menjadi 82,6 dengan persentase ketuntasan sebesar 85,3\%.

Kedua, selain prestasi belajar, aktivitas belajar siswa selama proses belajar-mengajar juga terjadi. Dimana pada siklus I pertemuan 1 kategori aktivitas belajar siswa kelas IX-4 SMP Negeri 1 Selesai Tahun Pelejaran 2016/2017 yaitu kategori kurang dan pertemuan 2

Meningkatkan Prestasi Belajar... (Ritonga, L.,68-82) 80 
adalah kategori cukup. Kemudian pada siklus II, aktivitas belajar siswa pertemuan 1 adalah kategori Baik dan pada pertemuan II adalah kategori Sangat baik. Kemudian, siswa lebih aktif dan atusias untuk merespon stimulus dari guru selama kegiatan belajar mengajar. Sekanjutnya, kemampuan murid memahami materi pembelajaran meningkat ini tampak dari banyaknya murid yang tuntas belajar. Demikian juga, hasil tes unjuk kerja siswa yang dilakukan oleh guru menunjukkan adanya peningkatan setiap siklusnya. Akhirnya, dalam proses perbaikan pembelajaran dengan menggunakan media dapat meningkatkan keterampilan guru dalam menggunakan media menambah pengetahuan dan wawasan terhadap materi pelajaran sehingga dapat menjadi guru yang profesional.

\section{Saran}

Berdasarkan kesimpulan di atas, beberapa hal yang disarankan untuk dilakukan oleh guru dalam pembelajaran mata pelajaran IPA. Pertama, guru sebaiknya selalu berupaya membiasakan anak berbicara dan menciptakan suasana kelas yang kondusif. Karena pada hakekatnya setiap anak normal berpotensi untuk meningkatkan prestasi belajar mereka masing-masing. Sekolah dan guru yang memungkinkan mengembangkan potensi kemampuan cara anak. Kedua, guru harus berusaha menyampaikan materi serta mengelola kelas, sehingga suasana pembelajaran dapat terus meningkat seiring dengan kemampuan yang dimilikinya. Terakhir, guru dalam pembelajaran IPA hendaknya menggunakan media sehingga mampu meningkatkan kualitas proses pembelajaran dan hasil pembelajaran.

\section{F. DAFTAR PUSTAKA}

Arifin, Z. 2009. Evaluasi Pembelajaran. Bandung: PT. Remaja Rosdakarya.

Arikunto, S. 1999. Prosedur Penelitian: Suatu Pendekatan Praktek. Jakarta: PT. Rineka Cipta.

Arsyad, A. 2011. Media Pembelajaran. Jakarta: Rajawali Pers.

Darmodjo, H. dan J.R.E. Kaligis. 1993. Pendidikan IPA 2. Jakarta: Depdikbud Dirjendikti.

Hadi, A. S. 2003. Multimedia Interaktif dan Flash. Yogyakarta: PT Graha Ilmu. 
Hofstetter, F. T. 2001. Multimedia Literacy. Third Edition. New York: McGraw-Hill. International Edition.

Maulana, M. E. dan Ono, Y. W. (2008). Modul Tata Surya. Diunduh pada http://staff.uny.ac.id/sites/default/files/lain-lain/ikhlasulardinugrohompd/

Sistem\%20Tata\%20Surya\%20ver_Akhir_hasil\%20proses\%2

0editing.pdf. Diakses pada tanggal 16 April 2016.

Philips. 1997. The Develophe's Handbook To Interactive Multimedia:

A Practical Guide For Educational Applications. London England: Kogan Page Limited.

Sagala, S. 2010. Konsep dan Makna Pembelajaran. Bandung: Alfabeta.

Sudijono, A. 1996. Pengantar Evaluasi Pendidikan. Jakarta: PT. Grafindo Persada.

Sulistyorini. 2007. Model Pembelajaran IPA Sekolah Dasar dan Penerapannya dalam KTSP. Yogyakarta: Tiara Wacana.

Syah, M. 2004. Psikologi Pendidikan. Bandung: Remaja Rosdakarya. 